\title{
EFFECT OF HYPERBARIC OXYGEN ON THE REGENERATION OF EXPERIMENTAL CRUSH INJURIES OF NERVES
}

\author{
Paulo Tuma Jr., Mariza D'Agostino Dias, Gino Arrunátegui, Gustavo \\ Gibin Duarte, Alexandre Wada, Armando Santos Cunha and Marcus \\ Castro Ferreira
}

RHCFAP/2967

TUMA Jr. P et al. - Effect of hyperbaric oxygen on the regeneration of experimental crush injuries of nerves . Rev. Hosp. Clín. Fac. Med. S. Paulo 54 (3): $81-84,1999$.

SUMMARY: Hyperbaric oxygen has been successfully used on treatment of acute ischemic injuries involving soft tissues and chronic injuries. In nerve crush injuries, the mechanisms involved are very similar to those found in ischemic injuries. Consequently, it is logical to hypothesize that hyperbaric oxygen should improve nerve repair, which is a critical step on functional recovery. In the present study, we created standard nerve crush injuries on sciatic nerves of rats, which underwent treatment with hyperbaric oxygen. Results were assessed by functional evaluation using walking-track analysis. The functional recovery indexes observed did not differ from control group. We concluded that hyperbaric oxygen therapy, in the schedule used, had no influence on functional recovery after nerve crush injuries.

DESCRIPTORS: Hyperbaric oxygen. Nerve regeneration. Nerve injury. Sciatic function index. Experimental study.

Therapy with hyperbaric oxygen (HBO) is an adjuvant treatment in some cases of acute trauma with ischemia, such as crush injuries of extremities, compartmental syndrome, poorly healing injuries, ischemic flaps, and radionecrosis of bone ${ }^{1}$.

Crush injuries and section of nerves may manifest a physiopathology similar to that associated with ischemia of muscle and skin flaps. In the initial period after the nerve damage, swelling and edema occur, as indicated by higher nerve weight caused by increase of water ${ }^{1}$.

Previous studies showed improvement in functional recovery when therapy with hyperbaric oxygen is used either after transection and suture $^{2}$ or when autologous nerve grafting is interposed ${ }^{3}$ in rat the sciatic nerve model. However, the same results were not seen with nerve tubulization after transection ${ }^{1}$, and in crush injuries of rat fibular nerves ${ }^{4}$.
Fibular nerve has better vascularization, compared to sciatic nerve, due to its smaller transverse section $\operatorname{area}^{4}$. The present study was designed to evaluate the influence of $\mathrm{HBO}$ in the functional recovery after crush injury in rats, using the sciatic nerve, which is theoretically more susceptible to ischemia than the fibular nerve.

\section{MATERIAL AND METHODS}

\section{Surgical Procedure}

Twenty Wistar male rats, weighting from 300 to $350 \mathrm{~g}$, with ages of around 8 weeks, were operated on under anesthesia using chloral hydrate in a concentration of $10 \%, 400 \mathrm{mg} / \mathrm{kg}$, intra-peritoneal injection. An incision

Division of Plastic Surgery, University of São Paulo School of Medicine - São Paulo, Brazil. was made dorsally on the right thigh. Through a muscle splitting incision, the sciatic nerve was exposed from the notch to its first division (Figure 1).

The crush injury of $1.5 \mathrm{~mm}$ was performed on the nerve, using a hemostatic "mosquito" forceps (Figure 2). As described by Dash ${ }^{5}$, the nerve was crushed $1 \mathrm{~cm}$ proximally to the bifurcation, for ${ }^{5}$ seconds, with the instrument closed to the first notch (Figure 3). After the procedure, the muscle and skin were closed, and the animals were placed in separated cages, with water and food ad libitum.

\section{Hyperbaric Oxygen Therapy}

Animals were randomized into two groups, A and B (Table 1). In the first group (A), animals received oxygen in a $100 \%$ concentration in an individual hyperbaric chamber, model Seechrist ${ }^{\circledR}$, under a 2.8 atmospheres pressure for 30 minutes, twice a day, 


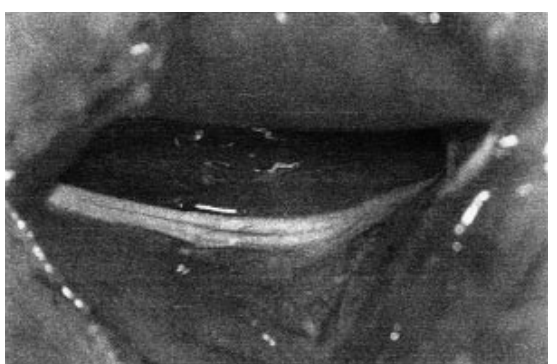

Figure 1 - Exposed sciatic nerve.

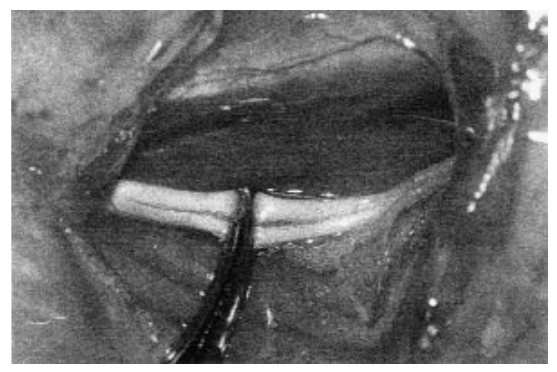

Figure 2 - Crush injury.

during three consecutive days. Therapy started at the first hour after the operation. The other group (B) did not receive hyperbaric oxygen after the injuries.

\section{Functional Evaluation}

Functional recovery was assessed using the walking-track analysis, according to the method previously described by Medinaceli et al. ${ }^{6}$ and modified by Bain et $\mathrm{al}^{7}$. The analyses were made before the surgery, and 2 , 15 and 30 days after.

In order to create foot prints on paper, animals had their posterior foot painted in blue ink and were placed on white paper in a track. Afterwards, the prints were measured, and the following measurements were taken: the distance between first and fifth toes (toe spread - TS), distance between second and fourth toes (intermediate toe spread - ITS), and the total length of the footprint (print length - PL).

The measures were used to calculate the Sciatic Function Index for each animal, as proposed by Bain ${ }^{7}$ :
$\mathrm{SFI}=[-38.3 \times(\mathrm{PLO}-\mathrm{PLN}) \div \mathrm{PLN}]+$

$[109.5 \times(\mathrm{TSO}-\mathrm{TSN}) \div \mathrm{TSN}]+$

$[13.3 \times($ ITSO - ITSN $) \div$ ITSN $]-8,8$

PLO $=$ length of the operated print

PLN $=$ length of the normal print

TSO $=$ operated toe spread

$\mathrm{TSN}=$ normal toe spread

ITSO $=$ intermediate operated toe spread

ITSN $=$ intermediate normal toe spread

Using this formula, the Sciatic Function Index (SFI) was calculated, and the values were classified as follows::

$\mathrm{SFI}=0+/-\rightarrow$ normal sciatic function

SFI $=-100+/-\rightarrow 12 \nRightarrow$ complete dysfunction

\section{Statistical Analysis}

The variable SFI was presented descriptively in a table containing mean, standard deviation, median, minimal values, and maximal values, for each group and evaluation condition.

The two factors, group and evaluation condition, were studied through the mean profile analysis, and the following hypotheses were tested:

- H01: the mean profiles are parallels and the groups have the same behaviour during the studied conditions.

- H02: the mean profiles are the same, and there is no difference between the means of the two groups on the conditions studied.

- H03: there is no influence of the condition factor, and the means are constant during the different conditions.

Significance level in this study was $<0.05$.

\section{RESULTS}

A SFI near 0 was observed in the measures made before the injuries, demonstrating normal function. Two days after the injury, the SFI decreased in both groups. After 15 days, the SFI was half-way towards zero, and in 30 days, the SFI was nearest to zero of the three measurements taken after injury (Table 2 and Graph 1).

There was no statistically significant difference between the $\mathrm{HBO}$ and control groups (Table 3).

\section{DISCUSSION}

Some nerve injuries are followed by hypoperfusion and edema. These changes can be detected almost immediately after a nerve injury ${ }^{1}$.

In any acute ischemic tissue, cellular changes occur, and they disturb the regulation of flow through the capillary membranes, leading to edema. This edema seems to be important in maintaining ischemia, because it compresses the microcirculation and decreases tissue perfusion. When the circulation is restored after long ischemic periods, physiologic shunts are opened, increasing the edema, resulting in a paradoxic ischemia (no-reflow phenomenon) ${ }^{8}$. HBO used early might interfere with this sequence by promoting vessel constriction, decreasing the flow and thus the edema. Hyperoxygenation would compensate for the decrease of flow, maintaining tissue oxygenation in suitable level ${ }^{8}$. Another possible mechanism of action associated with HBO is the decrease in the neutrophil linkage to the endothelial wall, which minimizes the delivery of free radicals produced by the reperfusion phenomenon ${ }^{8,9}$.

The intensity of these harmful factors on the neural structures, however, has not been established. Other possible actions of $\mathrm{HBO}$ would consist of increasing production of vascular and neural growth factors, which improves the tissue perfusion1. In spite of all these possible mechanisms, the exact cellular mechanism of action of $\mathrm{HBO}$ is not still completely understood ${ }^{1},,^{9,10}$.

Several schedules for treatment with $\mathrm{HBO}$ have been proposed, but 
Table 1 - Experimental Groups.

\begin{tabular}{lcc}
\hline Group & Number of rats & Available for study \\
\hline A & 10 & 8 \\
B & 10 & 5 \\
\hline
\end{tabular}

Table 2 - SFI (Sciatic Function Index) in control and HBO groups, before surgery, 2,15 e 30 days after surgery.

\begin{tabular}{lccccc}
\hline Group & Period & Mean & $\begin{array}{c}\text { Standard } \\
\text { Deviation }\end{array}$ & Minimal & Maxiimal \\
\hline CONTROL & 0 & -3.16 & 5.87 & -10.97 & 6.71 \\
$(\mathrm{n}=8)$ & 2 & -74.14 & 17.91 & -98.50 & -46.59 \\
& 15 & -44.21 & 9.69 & -75.95 & -21.23 \\
& 30 & -17.11 & 21.56 & -60.54 & 7.35 \\
HBO & 0 & -5.35 & 8.11 & -11.94 & 7.65 \\
$(\mathrm{n}=5)$ & 2 & -70.39 & 14.48 & -78.19 & -44.61 \\
& 15 & -62.15 & 12.63 & -76.16 & -47.95 \\
& 30 & -29.15 & 22.88 & -62.94 & -11.06 \\
\hline
\end{tabular}

Graph 1 - Comparison of mean SFI.
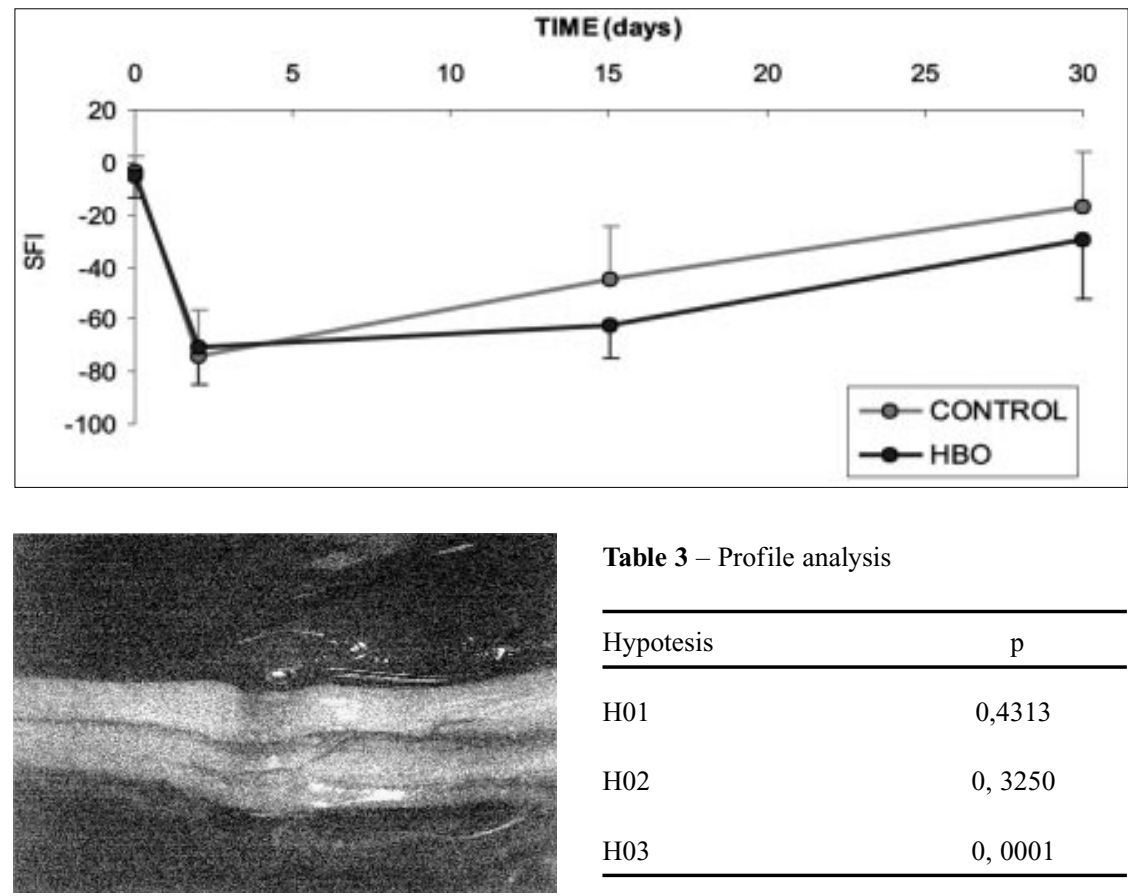

Table 3 - Profile analysis

\begin{tabular}{lc}
\hline Hypotesis & $\mathrm{p}$ \\
\hline $\mathrm{H} 01$ & 0,4313 \\
$\mathrm{H} 02$ & 0,3250 \\
$\mathrm{H} 03$ & 0,0001 \\
\hline
\end{tabular}

Figure 3 - Resultant nerve injury. there is not a standardized model that would be adequate for use in experimental animals. Pressures of more than three atmospheres during more than three hours, more than twice a day, are considered to have potential toxicity ${ }^{11}$. In this study, HBO was used an hour after the operation, and during three consecutive days, with a pressure of 2.8 atmospheres, for 30 minutes, twice a day. This proposed schedule seems to be adequate for this experimental model, and morbidity or death associated to the HBO was not observed.

Previous reports showed improve on functional recovery after rat sciatic nerve transection and autologous graft with the use of $\mathrm{HBO}^{2,3}$. On the other hand, the same was not observed in transections treated with tubulization ${ }^{1}$, and in crush injuries of rat fibular nerves ${ }^{4}$.

The crush injury differs from the transection injury because it produces axonotmesis, a functional impairment that returns to normal almost completely after three weeks from the injury, as observed in our control group, confirming the data by Dash et $\mathrm{al}^{5}$. Transection causes a injury in which spontaneous regeneration occurs only rarely. Consequently, HBO might have a more significant influence on nerve injuries with complete interruption by regulating the nerve environment, than it does with crush injuries, for which the external factors are less critical.

Results observed in this study agreed with the experiment performed by Santos et al. ${ }^{4}$ using crush injury, although the authors had used the fibular nerve and a different $\mathrm{HBO}$ schedule. Fibular nerve has better vascularization, compared to sciatic nerve. Although both have perineurial circulation, the fibular nerve has better vascularization because of its smaller transverse section area ${ }^{4}$. This difference seems not to interfere with functional evaluation after crush injuries of nerves in animals exposed to HBO. 
TUMA Jr. P e col. - Efeito da oxigenioterapia hiperbárica na regeneração de lesões experimentais de nervos. Rev. Hosp. Clín. Fac. Med. S. Paulo 54 (3): 81 - 84, 1999.

O oxigênio hiperbárico exerce efeitos comprovadamente benéficos no tratamento de lesões isquêmicas agudas de partes moles e em feridas de difícil cicatrização. Nas lesões neurais por esmagamento, os mecanismos fisiopatológicos assemelhamse aos efeitos dependentes da isque- mia tissular. Portanto, a terapia com oxigênio hiperbárico teria participação nos processos de reparação neural, que constitui um dos pontos críticos para a recuperação funcional após as lesões por esmagamento de nervos periféricos. Neste estudo, foram realizadas lesões por esmagamento em nervo ciático de ratos, submetidos à terapia com oxigênio hiperbárico no pós-operatório. Os resultados foram quantificados através de avaliação funcional pelo método de "walking- track analysis". Os índices de recuperação funcional observados não diferiram dos observados no grupo controle. Portanto, verificou-se que a terapia com oxigênio hiperbárico, no esquema proposto, não teve influência na recuperação funcional após lesões neurais por esmagamento.

DESCRITORES: Oxigênio hiperbárico. Regeneração neural. Lesão neural. Índice de função ciática. Estudo experimental.

\section{REFERENCES}

1. SANTOS PM, ZAMBONI WA, WILLIAMS SL et al. Hyperbaric oxygen treatment after rat peroneal nerve transection and entubation. Otolaringol Head Neck Surg, 1996; 114: 424-434.

2. ZAMBONI WA, BROWN RE, ROTH AC, et al. - Functional evaluation of peripheral nerve repair and the effect of hyperbaric oxygen. J Reconstr Microsurg, 1995; 11: 27-29.

3. GINGRASS M, ZAMBONI WA, BROWN RE, et al. - The effect of high tension oxygen on nerve regeneration in a nerve graft model. J Reconstr Microsurg, 1993; 9: 158.

4. SANTOS PM, WILLIAMS SL \& COVEY J - Peroneal motor nerve crush injury and hyperbaric oxygen effect . Laryngoscope, 1995; 105: 1061-1065.

5. DASH H, KONONOV A, PRAYSON RA, et al. - Evaluation of nerve recovery from minimal-duration crush injury. Ann Plast Surg, 1996; 37: 526-531.
6. DE MEDINACELI L FREED WJ \& WYATT RJ. - An index of the functional condition of rat sciatic nerve based on measurements made from walking tracks. Exp Neurol, 1982; 77: 634-643.

7. BAIN JR, MACKINNON SE \& HUNTER DA. - Functional evaluation of complete sciatic, peroneal, and posterior tibial nerve injuries in the rat. Plast Reconstr Surg, 1989; 83: 129-138.

8. NYLANDER G, LEWIS D, NORDSTROM H, et al. - Reduction of postischemic edema with hyperbaric oxygen. Plast Reconstr Surg, 1985; $76:$ 596-601.

9. ELLIS FR \& DEWAR KM - Effect of hyperbaric oxygen on nerve tissue. Br J Anesth, 1970; 42: 800.

10. MUKOYAMA M, IIDA M \& SOBUE I - Hyperbaric oxygen therapy for peripheral nerve damage induced in rabbits with Clioquinol. Exp Neurol, 1975; 47: 371-380.

11. DAVIS JC - Hyperbaric oxygen therapy: a committee report. Bethesda, Undersea Medical Society, 1983.

Received for publication on the 13/01/99 